\title{
Pharmaceutical care in Alzheimer's disease
}

\author{
Sandra Vezmar Kovačević \\ University of Belgrade - Faculty of Pharmacy, Department of Pharmacokinetics and \\ Clinical Pharmacy, Vojvode Stepe 450, 11221 Belgrade
}

Corresponding author: Prof. Dr Sandra Vezmar Kovačević

e-mail: svezmar@pharmacy.bg.ac.rs

\begin{abstract}
Summary
Alzheimer's disease (AD) is a neurodegenerative disorder characterized by progressive memory and cognitive function impairment as well as behavioural and psychiatric disturbances. Pharmaceutical care involves the process of identifying, resolving, and preventing drug-related problems, and it is aimed at improving the patient's quality of life. AD is usually diagnosed in elderly patients with comorbidities and, consequently, a variety of drug-related problems may occur. Pharmacists should focus on adverse reactions, drug-drug interactions, and adherence in patients with $\mathrm{AD}$. The introduction of acetylcholinesterase inhibitors in treatment may be associated with adverse effects, such as diarrhoea, muscle cramps, fatigue, nausea, vomiting, insomnia, anorexia, headache, and dizziness, which may be transient or require an alternative medication. Use of anticholinergic medications, bradycardia causing medications, antipsychotics and other medications should be assessed carefully because of potential drug-drug interactions with acetylcholinesterase inhibitors, especially rivastigmine. Adherence may be a major drugrelated problem in patients with $\mathrm{AD}$ because of the nature of illness and appropriate communication between pharmacists and patients or carers requiring adequate skills and knowledge. Although AD is increasing in prevalence there is a lack of evidence about the impact of pharmaceutical care on the treatment outcomes and quality of life of patients and more research is needed in this area.
\end{abstract}

Key words: Alzheimer's disease, pharmaceutical care, drug-drug interactions, adverse reactions, adherence 


\section{Introduction}

Alzheimer's disease (AD) is a neurodegenerative disorder characterized by progressive memory and cognitive function impairment as well as behavioural and psychiatric disturbances $(1,2)$. AD is the most prevalent form of dementia in Europe, and the global prevalence of the disease is expected to rise in the next decades $(3,4)$. Increasing disease prevalence is accompanied by rising costs in the healthcare system because of medical care utilization. The inclusion of the pharmacist in community-based, collaborative practises focused on individuals with $\mathrm{AD}$ and involvement of their caregivers is expected to improve patients' clinical outcomes while reducing the costs of the disease (5). Pharmacists are well-positioned and available healthcare professionals with skills and knowledge to assist patients with $\mathrm{AD}$ and their caregivers providing pharmaceutical care (6).

According to the Hepler and Strand definition ,pharmaceutical care is the responsible provision of drug therapy for the purpose of achieving definite outcomes that improve a patient's quality of life". These outcomes provide curing a disease, elimination or reduction of a patients' symptomatology, arresting or slowing down a disease process, or preventing a disease or symptomatology $(7,8)$. Pharmaceutical care involves the process of identifying potential and actual drug-related problems (DRPs), resolving actual DRPs, and preventing DRPs (7-9). Pharmaceutical Care Network Europe (PCNE) gives the following definition ,a DRP is an event or circumstance involving drug therapy that actually or potentially interferes with desired health outcomes" (10). DRPs can be classified in many ways; the newest PCNE classification (V9.0) distinguishes problems related to treatment effectiveness (no effect or suboptimal effect of drug treatment, the existence of untreated symptoms or indication), treatment safety (adverse drug events) and others (unnecessary treatment, etc.) (10).

The majority of people with AD are older than 65 years, and they are more likely to have comorbid conditions such as cardiovascular diseases and diabetes (11-13). Comorbidities often require long-term use of medications which increase the risk of DRPs, including cognitive impairment in patients with AD. This could be associated with a lack of adherence which can further worsen the outcomes of therapy (14-17). Moreover, low quality of life, poor disease outcomes, and increased hospitalizations and healthcare costs have been associated with poor medication adherence in the elderly (16-18).

When $\mathrm{AD}$ is diagnosed, patients and/or their carers are usually faced with a lack of understanding of the disease and its progression and treatment. They should be provided with information about medications, their indications and dosing regimens, adverse effects, and possible interactions. Effective medication management includes: management of drug interactions and adverse effects; use of as few medications as possible; adherence support and support services for patients and carers (5). Pharmaceutical care in patients with AD should involve the provision of ongoing support 
and education for patients and carers. Also, pharmacists may recognize clinical signs and symptoms of AD early-stage or mild cognitive impairment and refer the individuals to specialists. It is known that patients with mild cognitive impairment are at increased risk of developing $\mathrm{AD}$ and may benefit from early treatment (5).

As the disease progresses, changes occur in behaviour, mood, personality, and the ability of the patient to communicate effectively (19). Patients become increasingly in need to be assisted intensively with daily activities including feeding, dressing, bathing, medicines and behaviour management, as well as incontinence $(20,21)$.

Behavioural and psychological symptoms of dementia are often challenging to family and carers. Symptoms such as delusions, hallucinations, agitation or aggression, depression, anxiety, elation or euphoria, apathy or indifference, disinhibition, irritation or lability, a change in eating patterns and „wandering around" are included (19). As the disease progresses ,,sundowningИ occurs, which is the term when people have no sense of whether it is day or night, and subsequently, the patients awaken carers as they get up and dress in the middle of the night. Moreover, when agitation and aggression occur patients can be difficult to control, and this is a frequent reason for admission to longterm care (19).

\section{Treatment of Alzheimer's dementia}

Two pharmacological groups are currently licensed for the treatment of the symptoms of AD: the acetylcholinesterase inhibitors (AChEIs) donepezil, rivastigmine and galantamine, and the N-methyl-D-aspartate (NMDA) receptor antagonist memantine. The aim of the treatment is not to cure the disease, but to achieve independence as long as possible, maintain function and treat cognitive, non-cognitive, behavioural, and psychological symptoms (22). AChEIs are recommended treatment options for mild and moderate AD. Memantine is used for the treatment of mild or moderate AD for people who cannot take AChEIs and for the treatment of severe disease $(19,22)$. Significant improvement in cognition and activities of daily living, global outcomes, and less agitation have been observed with memantine (23). Memantine can be used as monotherapy or in combination with AChEIs.

The treatment usually starts with one AChEI. If a response to the medication is not seen, or intolerable adverse effects occur, it is justifiable to try another medication from the same group $(19,22)$. When initiating the treatment with an AChEI, improvement is expected compared to the pre-treatment function and assessment scores. However, as the disease progresses, individual patient performance will probably decline, eventually to a stage where the medication will seem to have little or no clinical effect. Nevertheless, even in those situations, the patient should stay on medication since functions in activities of daily living, cognitive function, and behaviour, will still be alleviated to some extent $(19,22)$. 


\section{Medication management and patient care}

The introduction of treatment for AD may cause a variety of DRPs. AChEIs should be started with caution in patients with the presence of supraventricular cardiac conduction impairment, asthma or chronic obstructive pulmonary disease (COPD) and risk of peptic ulcer disease. Caution is advised when rivastigmine is prescribed to patients with renal impairment or mild to moderate hepatic impairment $(6,19)$.

Gastrointestinal adverse effects such as diarrhoea, muscle cramps, fatigue, nausea, vomiting, insomnia, anorexia, headache, and dizziness are caused by all AChEIs. However, if these symptoms occur, the treatment should be continued since they may disappear in a short-term period. If the adverse effects are severe and result in significant weight loss, the medication can be taken after food, and/or with an anti-emetic. A 3-month assessment period is recommended to test the tolerability and clinical efficacy of one medication. If the patient cannot tolerate the effective dose or the medication is not effective an alternative should be considered $(6,19)$.

If nausea/vomiting occurs during AChEI treatment, domperidone or long-acting metoclopramide may be offered. Domperidone is the drug of choice because it does not cross the blood-brain barrier or have anticholinergic side effects. It should be taken regularly three or four times daily for 3 or 4 days. Thereafter, it should be reduced and discontinued along with the mildering of adverse effects $(6,19)$.

Loperamide may be offered to treat diarrhoea if necessary. The dose and frequency are usually titrated to control the adverse effect and then taken regularly. However, prolonged duration or too high doses of loperamide may cause constipation (19).

The adverse effects of memantine include dizziness, headache, confusion, hallucinations, and tiredness. If the patient is tired, short naps in the mid-afternoon may be helpful and the medication should be taken at night to aid sleep (19).

The patient should be advised to seek help from the prescriber if side effects of AChEIs and memantine are severe and/or debilitating, if signs of urinary flow difficulties or asthma worsening, COPD or cardiovascular symptoms, especially blackouts appear (19).

It is necessary to bear in mind that concomitant medications with antimuscarinic properties, including antipsychotics, tricyclic antidepressants, furosemide, digoxin, and others, may exacerbate or cause confusion in patients with $\mathrm{AD}(19,24)$.

When new medicines are introduced (including the purchase of over-the-counter products for coughs and colds) the pharmacist must be sure that they do not cause anticholinergic adverse effects because this will increase confusion, impair memory function, and possibly antagonise the effect of the AChEI. Drug-drug interactions should always be reviewed; the most important ones are presented in Table I. 
Table I The most important drug-drug interactions in the treatment of Alzheimer's disease (24).

\begin{tabular}{|c|c|}
\hline Interacting medications & Recommendation \\
\hline \multicolumn{2}{|l|}{ Acetylcholine esterase inhibitors (AChEIs) } \\
\hline $\begin{array}{l}\text { Anticholinergic Agents (i.e. amitriptyline; } \\
\text { atropine, } \mathrm{H}_{2} \text { receptor antagonists, ipratropium, } \\
\text { ketotifen) }\end{array}$ & $\begin{array}{l}\text { The therapeutic effect of medications may be diminished. } \\
\text { Avoid concomitant use if possible. Monitor for treatment } \\
\text { outcomes. }\end{array}$ \\
\hline Antipsychotic Agents & $\begin{array}{l}\text { Monitor for the development of extrapyramidal symptoms (e.g., } \\
\text { generalized rigidity, shuffling gait, facial grimacing) during } \\
\text { concomitant use. }\end{array}$ \\
\hline $\begin{array}{l}\text { Beta-Blockers and Bradycardia-Causing Agents } \\
\text { (i.e. amiodarone, digoxin, diltiazem, fingolimod, } \\
\text { ivabradine, methyldopa, propafenone, verapamil) }\end{array}$ & $\begin{array}{l}\text { Avoid the concomitant use of rivastigmine with beta-blockers. } \\
\text { Monitor for increased bradycardia, syncope, and/or hypotension } \\
\text { in patients receiving concomitant therapy with beta-blockers or } \\
\text { bradycardia-causing agents and other AChEIs. }\end{array}$ \\
\hline Corticosteroids (Systemic) & $\begin{array}{l}\text { Monitor for exacerbation of muscular weakness. Dose } \\
\text { reduction or tapering of AChEIs may be beneficial in the } \\
\text { setting of high-dose steroid use. }\end{array}$ \\
\hline Dipyridamole & $\begin{array}{l}\text { Monitor for decreased pharmacologic effects of AChEIs in } \\
\text { patients who are also receiving dipyridamole. }\end{array}$ \\
\hline Metoclopramide & $\begin{array}{l}\text { Avoid the concomitant use of rivastigmine and metoclopramide } \\
\text { because the risk of extrapyramidal adverse effects may be } \\
\text { increased }\end{array}$ \\
\hline $\begin{array}{l}\text { CYP2D6 Inhibitors (i.e bupropion, fluoxetine, } \\
\text { paroxetine) }\end{array}$ & $\begin{array}{l}\text { Monitor for increased effects of galantamine if used together } \\
\text { with a strong CYP2D6 inhibitor }\end{array}$ \\
\hline $\begin{array}{l}\text { CYP3A4 Inhibitors (i.e. clarithromycin, } \\
\text { itraconazole, ketoconazole) }\end{array}$ & $\begin{array}{l}\text { Monitor for increased effects of galantamine if used together } \\
\text { with a strong CYP3A4 inhibitor }\end{array}$ \\
\hline Tobacco (smoked) & $\begin{array}{l}\text { Monitor for reduced rivastigmine efficacy in patients who } \\
\text { smoke cigarettes and monitor for increased rivastigmine } \\
\text { effects/toxicities in patients who quit smoking during } \\
\text { rivastigmine therapy. }\end{array}$ \\
\hline $\begin{array}{l}\text { QT-prolonging Agents (i.e. amiodarone, } \\
\text { chlorpromazine, sotalol, terfenadine, ziprasidone) }\end{array}$ & $\begin{array}{l}\text { Monitor for QTc interval prolongation and ventricular } \\
\text { arrhythmias (including torsades de pointes) when donepezil is } \\
\text { used. Greater risk for ventricular arrhythmias is associated } \\
\text { with, older age, female sex, bradycardia, hypokalaemia, } \\
\text { hypomagnesemia, heart disease, and higher drug } \\
\text { concentrations. }\end{array}$ \\
\hline \multicolumn{2}{|l|}{ Memantine } \\
\hline $\begin{array}{l}\text { Alkalinizing Agents (i.e. Potassium Citrate, } \\
\text { Sodium Bicarbonate, Sodium Citrate, Sodium } \\
\text { Lactate) }\end{array}$ & $\begin{array}{l}\text { Monitor for increased effects/toxicity of memantine if co- } \\
\text { administered with alkalinizing agents that increase urinary } \mathrm{pH} \text {. }\end{array}$ \\
\hline $\begin{array}{l}\text { Carbonic Anhydrase Inhibitors (i.e. } \\
\text { acetazolamide, topiramate, zonisamide) }\end{array}$ & $\begin{array}{l}\text { Monitor for increased effects/toxicity of memantine if co- } \\
\text { administered with a carbonic anhydrase inhibitor. }\end{array}$ \\
\hline $\begin{array}{l}\text { NMDA Receptor Antagonists (i.e. } \\
\text { dextromethorphan, ketamine) }\end{array}$ & $\begin{array}{l}\text { Monitor for increased memantine adverse effects if combined } \\
\text { with another NMDA receptor antagonist. }\end{array}$ \\
\hline Trimethoprim & $\begin{array}{l}\text { Monitor patients for signs and symptoms of myoclonus and/or } \\
\text { delirium. If adverse effects develop discontinuation or dose } \\
\text { reduction of one or both agents may be necessary. Impaired } \\
\text { renal function is possibly associated with adverse effects. }\end{array}$ \\
\hline
\end{tabular}

AChEIs - acetylcholinesterase inhibitors; CYP - Cytochrome P 450; NMDA - N-methyl-D-aspartate 
Any medication with CNS effects (e.g. benzodiazepines, opiates, or dopaminergic agents) may negatively affect cognitive functioning (19).

Any agent which has the potential to confuse, e.g. long-acting hypoglycaemic agents and non-steroidal anti-inflammatory agents, should be carefully monitored and/or withdrawn if possible (19).

Treatment with AChEIs should be long-term since they delay disease progression by at least 6 months and some patients may benefit for periods of greater than 7 years (25). These agents prolong the possibility for family or carers to provide care in the home environment (26).

Antipsychotics are commonly prescribed to patients with AD when symptoms of agitation and aggression occur. However, the prescribing of antipsychotics may be inappropriate and associated with increased morbidity and mortality for as long as it is prescribed. Deaths associated with cerebrovascular and cardiovascular events, as well as pneumonia have been related to antipsychotic prescribing (27). As previously mentioned, highly antimuscarinic agents should be used with caution and their effect should be monitored because they can reduce cognitive functioning, and they are linked with increased mortality and morbidity (28).

Medication should be reviewed regularly and unnecessary use of medications should be avoided. It is important to ensure that the carer is involved in all aspects of medicines use because the carer is usually the person ensuring adherence to any medication regimen (19).

Various herbal supplements were expected to prevent and/or delay the onset of dementia. The evidence for improvement in cognitive functioning with ginkgo biloba is inconsistent. Ginkgo appears to be safe to use and is well tolerated however concomitant use with antithrombotics and anticoagulants should be avoided $(29,30)$. The efficacy of vitamin $\mathrm{E}$ in the prevention or treatment of people with $\mathrm{AD}$ has not been supported by evidence and the risks benefit ratio may be unfavourable (31). The dietary supplement folic acid, vitamin $\mathrm{B}_{12}$, and iron were not shown to improve cognitive impairment if a deficiency has not been identified (19).

The patient may have swallowing and chewing difficulties when the disease progresses. The use of liquid medication formulations may be helpful in some cases. However, crushing modified release forms to enable swallowing is not recommended. The provision of sip feeds may be useful in patients with reduced food and fluid intake (19).

Carers should be advised to remind patients about regular toileting (on waking and after meals and before bed) if control of bowels and bladder are reduced. Skin breakdown and possible pressure sores should be avoided by appropriate skincare (19). 
Exercise should be built into the daily routine, and dementia care environments should include areas where people can walk safely on their own. If the patient lives in his/her own home or with a carer, the surrounding should be adapted to the patient's possibility to move around safely $(6,19,32)$.

Maintaining a healthy diet is important especially in patients with cardiovascular risks associated with obesity. For patients who smoke, positive health benefits of stopping smoking should be emphasized, and nicotine replacement therapy suggested (6).

The benefits of social interaction and activities which stimulate memory have been shown in patients with AD. Social isolation should be avoided and stimulating activities depending on the patient's preference and physical ability such as social groups, local choirs, sporting activities should be promoted $(6,32)$.

\section{Communicating with people with dementia and their carers and supporting adherence}

People with dementia are able to communicate and they may enjoy the opportunity to talk to a pharmacist. When accurate and reliable information for medication history is needed, patients should be involved, but supporting information may be necessary from the caregivers $(6,19)$.

When communicating with people with dementia pharmacists should tackle and act on preserved memory systems. Following strategies are advisable:

- Sentences should be simple as well as the vocabulary.

- Information should be precise and understandable.

- The pharmacist should check if the patient (and the carer) understood the information.

- Information should be summarised at the end and written information provided.

- The speech should be slow, clear, and audible (19).

It is very important to offer support to carers since lack of support increases the probability of early institutionalisation (33). Information should be offered to patients and carers according to the stage of the illness, even if it is not always accepted. Patients or carers should understand the purpose of each medication and should be aware of adverse effects that may interfere with adherence and especially of those that need to be reported immediately. Information about medicines use should be offered to patients and carers in a precise manner. Directions such as ' $8 \mathrm{pm}$ ' or 'after breakfast' are useful so that dosing schedules can be planned according to mealtimes. If a medication is being taken for insomnia treatment should be advised to be taken $1 \mathrm{~h}$ before bedtime so that the medication is starting to take effect when the patient goes to bed (19). 
Medication regimens should be simplified. If possible, modified release forms with once-daily dosing should be preferred to medications with more frequent dosing $(5,6$, 19).

Patients should always use the same medication brand if possible, since patients may remember the shape and colour of the brand and get confused if alternatives are used. Memory and/or compliance aids and medication reminders may be helpful for patients and carers (19).

It is important to get confirmation from the patient or carer that all medicines are used. If there is non-adherence to one or more medications the reasons for it should be established. Usually, the reasons are lack of need for the medication or occurrence of adverse effects. Some adverse effects might be mitigated by a change of medication timing. I.e. donepezil has been associated with insomnia and/or nightmares which may be avoided if the medication is administered in the morning (19).

\section{Research in pharmaceutical care of patients with Alzheimer's dementia}

Although the role of the pharmacist as a healthcare professional in optimizing treatment of patients with $\mathrm{AD}$ is significant, the evidence regarding the identification of DRPs or the provision of pharmaceutical care by pharmacists in patients with $A D$ is scarce.

A study by Alzubaidi et al. investigated community pharmacists' knowledge of AD and its management, counseling skills, and dispensing patterns in patients with AD in the United Arab Emirates (UAE) (34). They revealed that when AD medications were requested, $24 \%$ of pharmacists reported that they asked the caregiver about the history of the disease; however, the questions were not specified. Most pharmacists provided counselling infrequently; $29.6 \%$ reported no or occasional counselling of patients or caregivers. Pharmacists counselling points were usually instructions on medication use (48\%), the indication of the medication (32.9\%), and possible adverse effects $(30.8 \%)$. Verbal communication of information to caregivers was reported by $36 \%$ of pharmacists, written and verbal communication was reported by $30 \%$, whereas $33.5 \%$ did not respond to this item. Adherence aids were not given to people with $\mathrm{AD}$ or their caregivers by more than half $(53.5 \%)$ of pharmacists and adherence to prescribed medications was not assessed routinely. The interventions were informing the caregivers $(7.1 \%)$ and consulting with the physician (7.1\%) when an adherence problem was discovered (34).

Another study by Pfister et al investigated the occurrence and character of DRPs in older hospitalized people with dementia and cognitive impairment. They found that ineffective drug/inappropriate drug and unnecessary drug therapy were the most common DRPs and the most common intervention was the discontinuation of medication therapy (35). 


\section{Conclusion}

Pharmacists are accessible healthcare professionals with adequate skills and knowledge to provide pharmaceutical care for patients with AD. Increased involvement of pharmacists in the provision of care of patients with $\mathrm{AD}$ could improve their treatment outcomes and quality of life. With the expected increase in the prevalence of the disease optimizing pharmaceutical care in patients with $\mathrm{AD}$ will be beneficial for the patients and the healthcare system. However, more evidence is needed to reveal the impact of pharmaceutical care on the clinical outcomes and quality of life of patients with AD.

\section{References}

1. Epperly T, Dunay MA, Boice JL. Alzheimers disease: pharmacologic and nonpharmacologic therapies for cognitive and functional symptoms. Am Fam Physicia 2017; 95(12):771-778.

2. Mc Khann GM, Knopman DS, Chertkow H, Hyman BT, Jack CRJ, Kawas CH et al. The diagnosis of dementia due to Alzheimer's disease: recommendations from the National Institute on AgingAlzheimer's Association workgroups on diagnostic guidelines for Alzheimer's disease. Alzheimers Dement 2011;7(3):263-269.

3. World Alzheimer Report 2018. The state of the art of dementia research: New frontiers. Alzheimer's Disease International, London, UK. Available at: https://www.alz.co.uk/research/WorldAlzheimerReport2018.pdf

4. Brookmeyer R, Johnson E, Ziegler-Graham K, Arrighi HM. Forecasting the global burden of Alzheimer's disease. Alzheimers Dement 2007;3(3):186-191

5. Skelton, JB. White paper on expanding the role of pharmacists in caring for individuals with Alzheimer's disease. J Am Pharm Assoc (2003) 2008;48(6):715-721.

6. NHS Education for Scotland. The Pharmaceutical Care of People with Dementia https://www.nes.scot.nhs.uk/media/4104909/pharmaceutical-care-of-people-with-dementia2014.pdf

7. Hepler CD, Strand LM. Opportunities and Responsibilities in Pharmaceutical Care. Am J Pharm Educ 1989;53(suppl):7S-15S

8. Hepler CD, Strand LM. Opportunities and Responsibilities in Pharmaceutical Care. Am J Hosp Pharm 1990;47(3):533-543.

9. European Directorate for the Quality of Medicines and HealthCare (EDQM). Pharmaceutical Care Policies and Practices for a Safer, More Responsible and Cost-effective Health System https://www.edqm.eu/medias/fichiers/policies_and_practices_for_a_safer_more_responsibl.pdf

10. Pharmaceutical Care Network Europe (PCNE). https://www.pcne.org/working-groups/2/drugrelated-problem-classification 
11. Yaghmour SM, Bartlett R, Brannelly T. Dementia in Eastern Mediterranean countries: A systematic review. Dementia (London) 2019;18(7-8):2635-2661.

12. Finegold JA, Asaria P, Francis DP. Mortality from ischaemic heart disease by country, region, and age: Statistics from World Health Organisation and United Nations. Int J Cardiol 2013;168(2): 934945.

13. Forouhi NG, Wareham NJ. Epidemiology of diabetes. Medicine (Abingdone) 2014;42(12):698-702

14. Bushardt RL, Massey EB, Simpson TW, Ariail JC, Simpson KN. Polypharmacy: Misleading, but manageable. Clin Interv Aging 2008;3(2):383-389.

15. Masnoon N, Shakib S, Kalisch-Ellett L, Caughey GE. What is polypharmacy? A systematic review of definitions. BMC Geriatr 2017;17(1): 230.

16. Brady R, Weinman J. Adherence to cholinesterase inhibitors in Alzheimer's disease: A review. Dement Geriatr Cogn Disord 2013;35(5-6);351-363.

17. Small G, Dubois B. A review of compliance to treatment in Alzheimer's disease: Potential benefits of a transdermal patch. Curr Med Res Opin 2007;23(11):2705-2713.

18. Chisholm-Burns MA, Spivey CA. The "cost" of medication nonadherence: Consequences we cannot afford to accept. J Am Pharm Assoc (2003) 2012;52(6): 823-826.

19. Taylor D. Dementia. In Clinical Pharmacy and Therapeutics, eds. Whittlesea C, Hodon K. 6th ed, Elsevier. 2019, pp 557-579.

20. Prince M, Wimo A, Guerchet M, Ali G-C, Wu Y-T, Prina M. World Alzheimer Report 2015. The Global Impact of Dementia: An analysis of prevalence, incidence, cost and trends. Alzheimer's Disease International, London, UK. Available at: https:/www.alz.co.uk/research/world-report-2015

21. Alzheimer's Association. 2017 Alzheimer's disease facts and figures. Alzheimers Dement 2017;13:325-373.

22. National Institute for Health and Care Excellence (NICE), 2016. Donepezil, galantamine, rivastigmine and memantine for the treatment of Alzheimer's disease. Technology appraisal guidance [TA217]. Available at: https://www.nice.org.uk/guidance/ta217.

23. Hermann N, Li A, Lanctôt K. Memantine in dementia: a review of the current evidence. Expert Opin. Pharmacother. 2011;12(5):787-800.

24. Lexi-interact ${ }^{\circledR}$ Lexi-Comp Inc. Available at: https://online.lexi.com

25. Livingston G, Katona C. How useful are cholinesterase inhibitors in the treatment of Alzheimer's disease? A number needed to treat analysis. Int J Geriatr Psych 2000;15(3):203-207.

26. Geldmacher DS, Provenzano G, McRae T, Mastey V, Ieni JR.. Donepezil is associated with delayed nursing home placement in patients with Alzheimer's disease. J Am Geriatr Soc 2003;51(7): 937944.

27. Wang PS, Schneeweiss S, Avorn J, Fischer MA; Mogun H, Solomon D, et al. Risk of death in elderly users of conventional vs. atypical antipsychotic medications. N Engl J Med 2005;353(22): 23352341.

28. Fox C, Livingston G, Maidment ID, Coulton S, Smithard DG, Boustani M, et al. The impact of anticholinergic burden in Alzheimer's dementia - the Laser-AD study. Age Ageing 2011;40(6):730735 . 
29. Birks J, Grimley Evans J. Ginkgo biloba for cognitive impairment and dementia. Cochrane Database Syst. Rev. 2009 (1), Art. No. CD003120. https://doi:10.1002/14651858.CD003120.pub3.

30. Bent S, Goldberg H, Padula A, Avins AL. Spontaneous bleeding associated with ginkgo biloba: a case report and systematic review of the literature. J Gen Intern. Med 2005;20(7):657-666.

31. Farina N, Isaac, MG, Clark AR, Rusted J, Tabet N. The use of vitamin E for Alzheimer's dementia and mild cognitive impairment. Cochrane Database Syst. Rev. 2012 (11) Art No., CD002854. https://doi:10.1002/14651858.CD 002854.pub3.

32. National Institute for Health and Care Excellence, Social Care Institute for Excellence (NICE-SCIE), 2011. The NICE-SCIE guideline on supporting people with dementia and their carers in health and social care. Available at: https://www.nice.org.uk/guidance/cg42/.

33. Eska K, Graessel E, Donath C, Schwarzkopf L, Lauterberg J, Holle R. Predictors of institutionalization of dementia patients in mild and moderate stages: a 4-year prospective analysis. Dement Geriatr Cogn Dis Extra 2013;3(1):426-445.

34. Alzubaidi H, Saidawi W, Hussein A, Hasan S. Critical role of pharmacists in caring for Alzheimer's disease patients. J Alzheimers Dis 2020;73(3):1253-1264.

35. Pfister B, Jonsson J, Gustafsson M. Drug-related problems and medication reviews among old people with dementia. BMC Pharmacol Toxicol 2017;18: 52. 


\title{
Farmaceutska zdravstvena zaštita u terapiji Alchajmerove demencije
}

\author{
Sandra Vezmar Kovačević \\ Univerzitet u Beogradu - Farmaceutski fakultet, Katedra za farmakokinetiku i kliničku \\ farmaciju, Vojvode Stepe 450, 11221 Beograd, Srbija
}

Autor za korespondenciju: svezmar@pharmacy.bg.ac.rs

\section{Kratak sadržaj}

Alchajmerova bolest (AD) je neurodegenerativni poremećaj koji karakteriše progresivno oštećenje pamćenja i kognitivnih funkcija, kao i bihejvioralni poremećaj pacijenta. Farmaceutska zdravstvena zaštita je proces koji uključuje identifikaciju, rešavanje i sprečavanje pojave problema povezanih sa terapijom sa ciljem postizanja ishoda koji poboljšavaju kvalitet života pacijenta. AD se obično dijagnostikuje kod starijih pacijenata sa komorbiditetima i mogu se pojaviti različiti problemi u vezi sa terapijom. Potrebno je da farmaceuti posebno obrate pažnju na neželjene reakcije na lek, interakcije lekova i adherencu kod pacijenata sa AD. Uvođenje inhibitora acetilholinesteraze u terapiju može biti povezano sa neželjenim reakcijama na lek, kao što su dijareja, mišićni grčevi, umor, mučnina, povraćanje, nesanica, anoreksija, glavobolja i vrtoglavica, koji mogu biti prolazni ili zahtevati promenu leka. Upotrebu antiholinergičkih lekova, lekova koji izazivaju bradikardiju, antipsihotika i drugih lekova treba pažljivo razmatrati zbog potencijalnih interakcija navedenih lekova sa inhibitorima acetilholinesteraze, posebno rivastigminom. Adherenca može biti važan problem u vezi sa terapijom kod pacijenata sa $A D$ zbog prirode bolesti, a veštine i znanja farmaceuta su neophodni da bi komunikacija sa pacijentima ili negovateljima bila odgovarajuća. Iako se učestalost AD povećava, nedostaje dokaza o uticaju farmaceutske zdravstvene zaštite na ishode terapije i kvalitet života pacijenata, stoga je potrebno više istraživanja u ovoj oblasti.

Ključne reči: Alchajmerova demencija, farmaceutska zdravstvena zaštita, neželjene reakcije na lek, interakcije, adherenca. 